医が取扱ら場合，トラブル発生して全くお手上 げとなってしまらことは明らかである。従って 臨床用実用機には (A)トラブル検出機構， (B) 保 全機構が備えられていなければならないと結論 される。

トラブル検出機構は図 3 に示すように, 空気 圧 8 力所, 電圧, 電流 10 力所, 空気圧波形 2 力 所, 血流量 2 所安連続計測し，この計測值を A-D変换し，あらかじめプログラムされた正常 範囲との比較をマイクロプロセッサで行らこと により異常を検出できる.トラブルの検出は， 血流量吕 $80 \sim 100 \mathrm{~m} l / \mathrm{kg} / \mathrm{min}$ ，空気圧波形は図 4 亿示す基準内であることを正常とし，これ以 外はトラブル発生として図 5 のフローチャート に従って実行する。そして結果を表示する.

人工心臓システムは故障停止の許容時間が極 めて短く, 循環停止による不可逆性の器質変化 が生体の臟器に発生する前に修理を完了してし まわねばならない，この極めて短い，わずか数 分以内の修理時閒で必要な部品の供給, 交換を 行うのは各部のユニット化と常時ストックによ り解決されるが，これに必要なスペースは駆動 装置自体の約 $60 \%$ にもなってしまう，保全の時 間短縮，容易さ，確実性から考えると，む51 台全く同し駆動装置を予備機として待機させ， 故障発生時には予備機に切替る方式をとるのが 信頼性から多て最上であると考えられる。

\section{まとめ}

人工心臟動物実験での長期生存成績の向上か ら，当施設の人工心臟は良好な抗血栓性，生体 適合性，耐久性をもつことが証明されてきた が，人工心臟が臨床使用されるに至るなでには まだ克服されねばならないハードウェア上のギ ヤップが残されている，前述のよらに実験機で は故障対策は熟練したスタッフによる24時間連 続監視と保全により解決されてきたが，一般臨 床使用ではこの故障発見と対処を一般臨床医, 看護婦，技師に負わせるわけにはいかず，どう してもハードウェア自身で故障検出, 警告, 対 応を行ら必要があることが明らかとなった。こ 晾の故障検出，対応機構を内蔵してはじめて 実用的な臨床用人工心臓システムとして使用が 可能となる。

今後の課題は, この故障検出, 対応機構を備 えることにより生ずる未評価の部分の評価であ る. 故障検出, 対応機構にも, それ自体故障の 可能性がある：従って定期的に人閒によるチェ ックが必要となろう。また人工心蔵の運転中は これらの計測パラメータをすべて記録すること が運転中に生ずる事象を正確に把握するために 必要不可欠であるといえる。

\section{参考文献}

1）滝戸・他；空気駆動型人工心臓システムの耐久 性の評価，医用電子と生体工学，19, 特別号, $54,1981$.

\title{
44. われわれの行っている心筋保護法
}

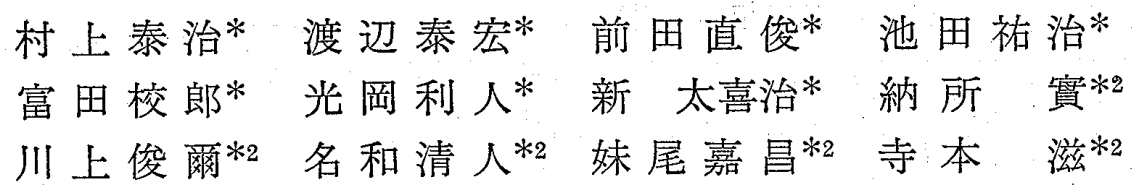

開心術手技の進歩は目覚ましいもものがり， 手術死は著明に減少してきている。開心術中の 心筋保護の重要性が注目され種々の工夫がされ

* 岡山大学中央手術部

*2 岡山大学第 2 外科
てきたことが手術死減少の大きな要因であるこ とは誰もが認めるところである゙。ここではわ れわれの施設で行っている心箭保護法の工夫と その結果について述べてみたい。 


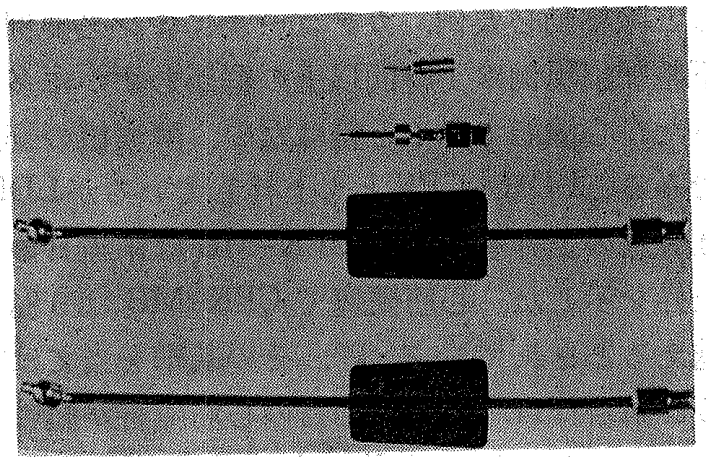

国

\section{方 法}

大䡃脈穿刺と空気抜きに用いる針は成人用で は16G，小胃用では18Gで注入压娍少と空気校 きを完全にするために橡に切れ込みを入れてあ る. 大動脈彻開を要する症例化は Kay の冠海 流カニュラを用いている(図 1)，心停止および 灌流波はテルモ社製テルパック輸液バッグを用 い加圧バッグを用いて $300 \mathrm{mmHg}$ まで加庄す る.バッグと針を接絽するチューブは岡大式心 冷却用チューブを用い注入塍の抵抗を诚らすよ らエ夫した.

われわれは心侮止液と满流命却液は同じ液を 用いている．生理的食塩水を基本とし塩化カリ ウ $440 \mathrm{mM}$, 硫酸マグネシウム $16 \mathrm{mM}$, 其政プロ カイン $1 \mathrm{mM}$, グルクロン酸かルシウム $5 \mathrm{mM}, ク ゙$ ルコース10g，重灰酸ナトリウム168mg を加え $\mathrm{pH} 7.5$ 浸透压 $430 \mathrm{mOsm} / l$ て, $4^{\circ} \mathrm{C}$ 次命却して用

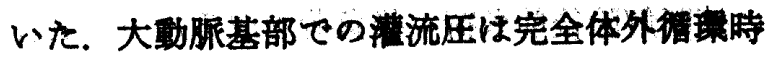
には平均 $55 \mathrm{mmHg}$ ，大峌根を遮哳すると75と なり冠㜔流を始めると95まで上年十るが，心拍 動が停止すると35まで下降しこの状热で命却液 を $800 \mathrm{cc}$ まで注入する，局库冷却を併用すると 約 10 分間で心筋温は $10^{\circ} \mathrm{C}$ 前後まで下降する,

\section{结，果}

昭和55年 1 月より 56 年 4 月までに行った体外 循誛症例は119例でその内69例に心传止掵却法 を用いた。疾患は并膜症 46，先天奇型 $20 ，$ 冠 動脈疾患 2 ，大動脈痹 1 である。行った手術は 表 1 のごとくである. 手術死は 3 例，病院死 1

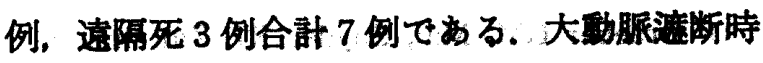
間が60分以内は36例，61から120分まで29例， 121 から 180 分まで3例，181分以上 1 例て乎術 死 3 例は 61 から 120 分の 3 例であるが 1 例は呼 a1

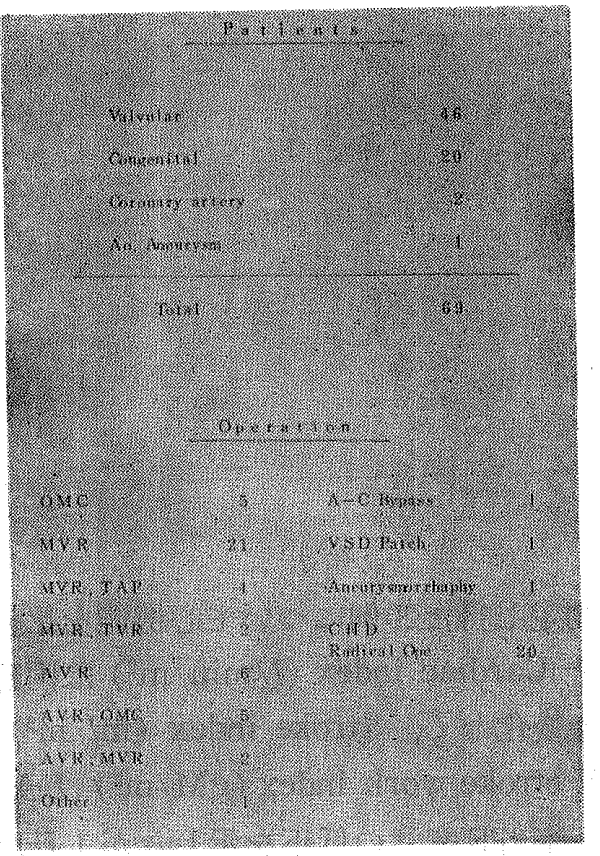

吸不全，1例は術中のポンプ流量不足で残りの 1 例のみ低心拍出量で失った。

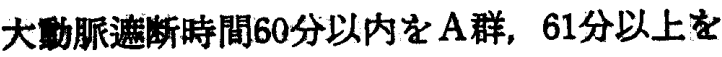
B群とするとA群 36 例，B群 33 例である。平

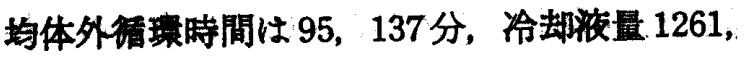
2491cc，除緗㽖を要したもの6 例(17\%)，6例 (18\%)，カテュールナミンを必要とした症例は $59 \% ， 69 \%$ ，不整脈出現は $42 \% ， 55 \%$ ，手術死 はB群に 3 例 ( $9 \%$ ) であった(表 2 )。

郝前カテーテル検㚗むよび街後ICUで心拍出

表 2

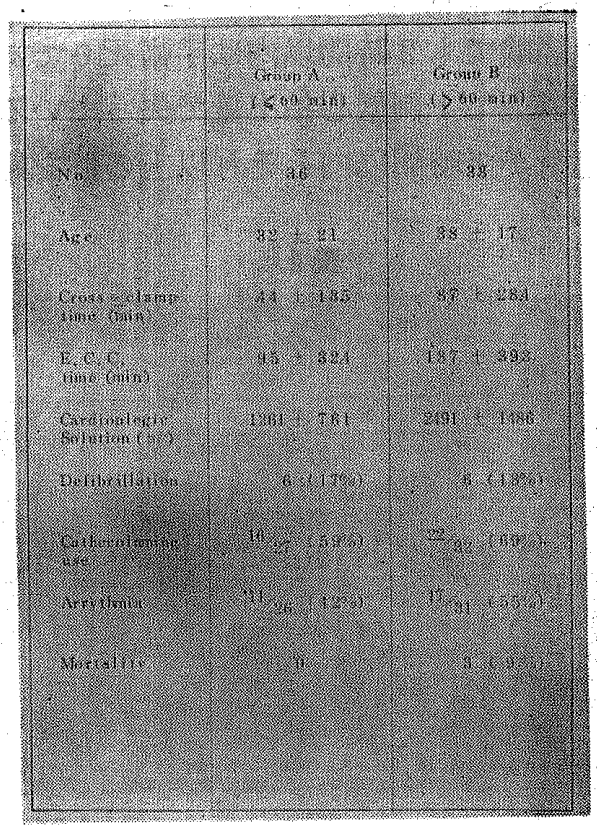


容了

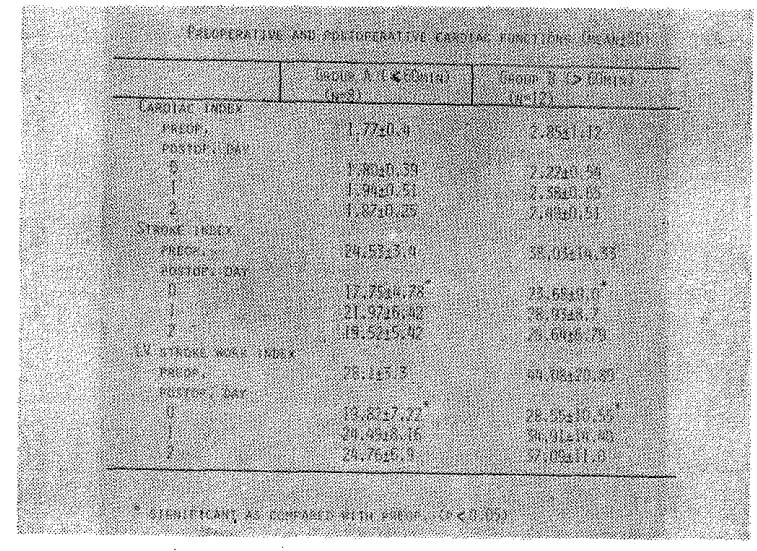

量を測定し得た20例について心機能を比較して みると Cardiac index $\left(l / \mathrm{min} / \mathrm{m}^{2}\right)$ は再群とも 有意な変化なく，Stroke index $\left(\mathrm{ml} / \mathrm{m}^{2}\right)$ およ び LV stroke work index $\left(\mathrm{gM} / \mathrm{m}^{2}\right)$ は A, B両 群とも術当日有意の低下を示したが 1 日以後は 術前値にまで回復した(表 3 )。

術前, 術後 $\mathrm{LDH}$ (Units), $\mathrm{CPK}(\mathrm{mU} / \mathrm{ml})$ を 湖定し得たものは17例である. LDH は街後 1 週間高値を示し CPK は術後 3 日まで有意に上 畀した. $\mathrm{LDH}_{1}$ アイソザイム (\%) は有意の上昇 がみられず, CPK-MB（\%）㤹当日のみ有意 の上昇を示し，total CPK とは異なった推移を 示した(表 4 ),

\section{考 案}

カリウムによる速やかな心停止と泠却液によ る $20^{\circ} \mathrm{C}$ 以下の心筋冷却により 2 時間の大動脈 遥断は安全と考えられるよらになった

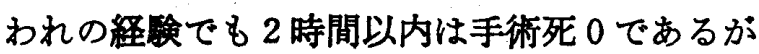
2 時間以上で 1 例低心拍出量で失っている. 大 動脈遮断が 1 時間以内とそれ以上の群を比較す

\section{4}

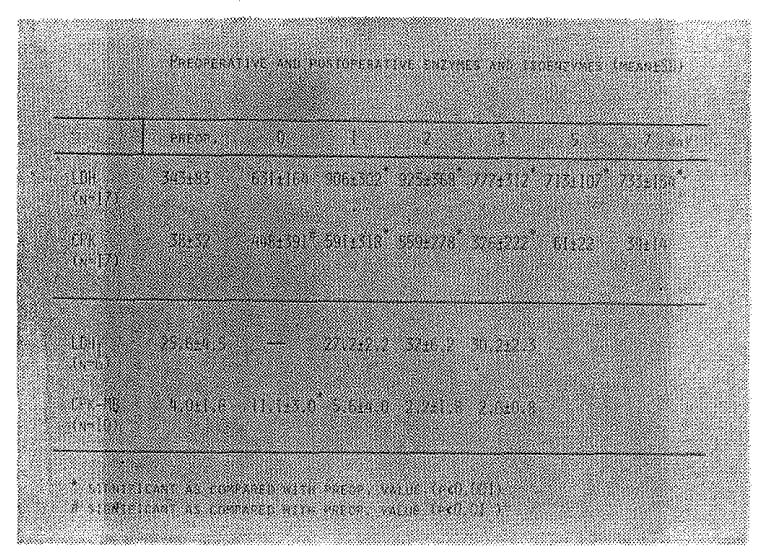

ると除細鲚必要例，カテコールテミン必要例， 不柴槚出現例は 1 时间以上の群がわずかに多か

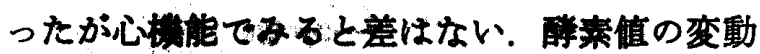
でみるとLDH，CPKとも上年しているが $\mathrm{LDH}_{1}$

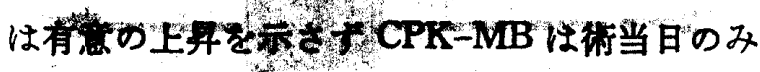
上年を示した，心施硬塞で CPK-MB は $5 \%$ \%を 越えるとされているが，その基準を当てはめ

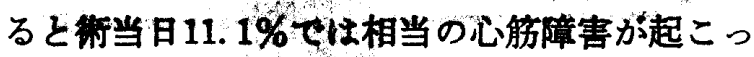
ていることになるが Engelman'2) によれば冠動 脈疾患に比べて弁膜疾患では術前心筋障害がよ り強く, 左室肥大による心内膜下の虚血が起こ りやすく，さらに心筋切開，切除等心内操作が 必要となりそれだけ心筋由来の酵素值の上界を きたすと述べている．われわれの症例では弁膜 疾患が67\%と大部分を占めているので上記のよ らな值が出たものと思われる。しかし左室肥大 があり心㬳障害の強い症例に対する 3 時間以上 の大動脈逘断はまだ問題が残されていると思わ れる。 $22^{\circ} \mathrm{C}$ で心停止下の心筋酸素消費量は常

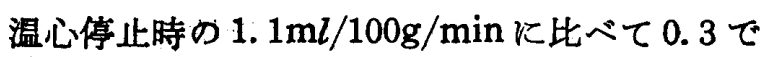
1/3 以下に低下しているが，この酸素需要を満 たすために間歌的に命却した血液を灌流させる 方法も考案され長時間遮断に対して有用である ことが報告されている4)：心筋のエネルギ消費 を減らすために冷却とカルシウム拮抗剤の使用 が注目され，より確実な心筋の弛緩と術後のよ ク安定した血行動態が報告されている5：さら に遮断解除後前角荷，後負荷を取るための血管 桩張昘の投与、IABP を含む補助循環の使用ま でを含めて総合的に考えることが心筋保護の効 果を上げるのに必要と考える:

\section{文嗝}

1) Braimbridge $\mathrm{MV}$ : Equipment for inducing cold cardioplegic arrest. J. Thorac Cardiovasc Surg 77; 323; 1979.

2) Engelman RM, Rousou JH, Vertrees RA, Rohrer CR, Auvil.J: Safety of prolonged ischemic arrest using hypothermic cardioplegia. J Thorac Cardiovasc Surg 79: 705, 1980.

3) Graeber GM, Maj, Snyder R, Zajtchuk R, Col, Brott WH: A comparison of serum isoenzyme levels of creatine phosphokinase and lactic dehydrogenase in patients under- 
医器学 Vol. 51, Suppl. (1981)

going thoracic operations and patients admitted to a coronary care unit. Ann Thorac Surg 30:364, 1980.

4) Laks H, Barner HB, Kaiser: Cold blood cardioplegia. J Thorac Cardiovasc Surg 77 : 319,1979

5) Vouhé PR, Hélias J, Grondin CM: Myocardial protection through cold cardioplegia using diltiazem, a calcium channel blocker. Ann Thorac Surg 30:342, 1980

付 議
大動脈切開時の際, 左右の冠動脈口への冠流 量はどの位か。

回：答

岡山大中央手術部 村上泰 治

冠流量は直接測定はしていませんが成人の場 合約 $800 \mathrm{ml}$ の灌流液を10分以内に入れています のでそれから計算できると思います。なお右の 冠動脈口に挿入できない例がかなりまりまして $1 / 3$ 位の症例に左のみの灌流を余儀なくされて 打ります。すう少し工夫が必要と考えて拉りま 于.

45. PADを応用したバイパスパンピング法の回路 系㳊関する研究

—特にリザーバについて—

小田桐重遠* 長 野 忠* 石倉義 弥* 村上基 博*2

\section{はじめに}

Intra Aortic Balloon Pumping (以下IABP 法）の効果の及ばない症例，またはバルーンの 挿入の不能な症例に対する機械的補助手段法と して Pulsatile Assist Device(以下 PAD)を応 用した tubular type の pulsatile pump 研 究開発してきた 改良を加え，動物実験にてその効果について検 討を加えた。

\section{回路系}

図 1 亿従来より行ってきた方法の回路系を示 す、V-A バイパスの場合は右房より，左心バ イパスの場合は左房より脱血し, 熱交換器を通 り硬質アクリル製のリザーバに貯血される（こ のリザーバ虫 2 飞示すようにV-A バイパス で万一高流量になった場合に人工肺がただちに 組み込めるように設計されている)，次に PAD および前後の弁機構よりなるポンプ部分へと流 入する。

* 産業医科大学第 2 外科

*2 産業医科大学 $\mathrm{ME}$ 部門

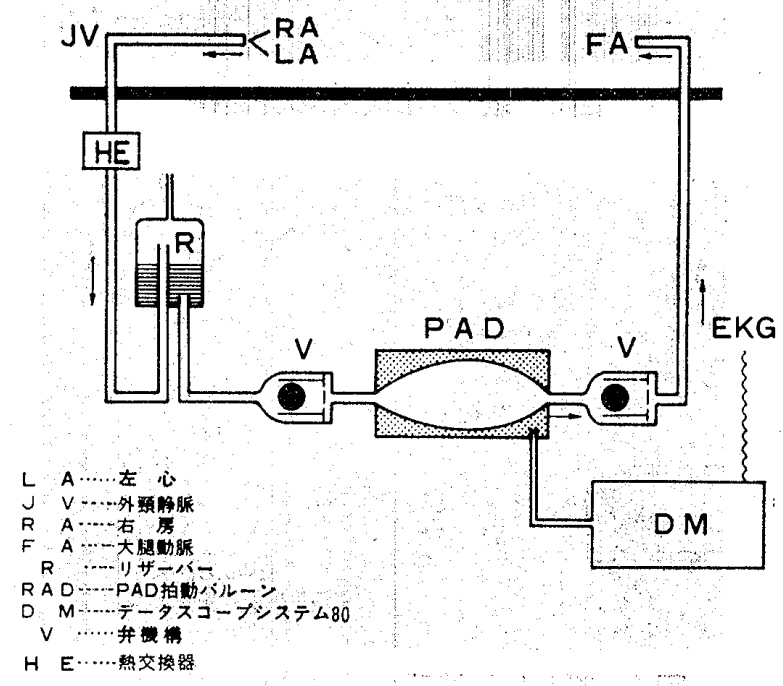

図1 本法における回路系のシェーマ

PAD の balloon membrane はポリウレタン 製で容量は $80 \mathrm{~m} l$ である。後方の弁は外装はス テンレス製で，後方の弁には人士弁用中空金属 ボール（比重＝0.95）, 前方の弁にはシリコン ボール（比重＝1.13）を用いた。これは本法が 流量補助に加えるに counterpulsation を电兼称 ることを意図したために前方の弁機構において 適度の逆流を必要とする。したがって前方の弁 